Introduction Palivizumab is a monoclonal antibody that reduces the likelihood of serious respiratory tract infection by Respiratory Syncytial Virus (RSV) in infants with Chronic Lung Disease (CLD) defined as an ongoing oxygen requirement at 36 weeks corrected gestation. In the UK (UK), Palivizumab is offered to high-risk infants with moderate to severe CLD according to their chronological age at the time of RSV season as per Joint Committee on Vaccination and Immunisation (JCVI) guidelines. The American Academy of Paediatrics, in contrast, recommends Palivizumab prophylaxis for all infants born before 29 weeks' gestation who are younger than 12 months at the start of the RSV season.

Materials and Methods We hypothesised that the RSV hospitalisation rate and length of hospital stay (LOS) within the 1 st year of life between preterm babies with CLD immunised according to the JCVI criteria (CLDJCVI) and the additional babies who are considered eligible by the AAP criteria would be comparable. Our cohort included babies born in Nottingham UK between 2009 and 2015. Data was collected from hospital records and the Nottingham CLD database, and analysed using Fisher's exact test for proportions and Mann-Whitney test for continuous data.

Results In total there were 3478 babies born preterm $(<37$ weeks GA) in Nottingham UK from 2009 to 2015. 459 babies were born in Nottingham at $<29$ weeks GA. 245 babies had CLD at 36 weeks corrected GA and 135 of these babies were eligible for Palivizumab (JCVI).

\begin{tabular}{llll}
$\begin{array}{l}\text { Abstract P81 Table } 1 \\
\text { average LOS }\end{array}$ & The number of babies hospitalised and the \\
\hline Number of babies & $\begin{array}{l}\text { Babies } \\
\text { immunised } \\
\text { according to } \\
\text { JCVI criteria }\end{array}$ & $\begin{array}{l}\text { Additional babies } \\
\text { who would be } \\
\text { eligible by AAP } \\
\text { criteria }\end{array}$ & $\begin{array}{l}\text { p } \\
\text { Value }\end{array}$ \\
\hline $\begin{array}{l}\text { Total } \\
\begin{array}{l}\text { Confirmed RSV hospitalisations } \\
\text { following discharge from neonatal } \\
\text { unit within 1 st year of life }\end{array}\end{array}$ & $\begin{array}{l}13(9.6 \%) \\
\text { Average LOS in days (IQR) }\end{array}$ & $13(8.13 \%)$ & 0.68 \\
\hline
\end{tabular}

Conclusion The RSV hospitalisation rate and LOS were not statistically different in babies under JCVI criteria and additional babies qualifying by AAP criteria. A larger multi-centre prospective study is required to prove health and economic benefits of adopting AAP Palivizumab recommendations.

\section{P82 COMPARISON OF RSV HOSPITALISATION IN PRETERM INFANTS WITH CHRONIC LUNG DISEASE WHO DO NOT QUALIFY FOR PALIVIZUMAB PROPHYLAXIS WITH THOSE WHO QUALIFY IN NOTTINGHAM, UK}

L Tsilika, D Batra, AP Prayle, M Hurley, JM Bhatt. Nottingham Children's Hospital, Nottingham, UK

\subsection{6/thoraxjnl-2017-210983.224}

Introduction Palivizumab prophylaxis reduces the likelihood of serious respiratory tract infection by Respiratory Syncytial Virus (RSV) in ex-preterm infants with Chronic Lung Disease (CLD). The Nottingham CLD service follows the Joint Committee on Vaccination and Immunisation (JCVI) guidelines for
Palivizumab prophylaxis based on gestation, respiratory status and chronological age at the beginning of RSV season. This retrospective observational study was conducted to compare the RSV hospitalisations in preterm infants with CLD who are offered Palvizumab to those with milder CLD.

Materials and Methods We hypothesised that the RSV hospitalisation rate and length of hospital stay (LOS) within the 1 st year of life between preterm babies in home oxygen with CLD immunised according to the JCVI criteria and babies with moderate CLD not discharged in home oxygen would be comparable. Our cohort included babies born in Nottingham UK between 2009 and 2015. Data was collected from hospital records and the Nottingham CLD database, and analysed using Fisher's exact test for proportions and Mann-Whitney test for continuous data.

Results In total there were 3478 babies born preterm $(<37$ weeks GA) in Nottingham UK from 2009 to 2015. 245 babies had CLD at 36 weeks corrected GA. 192 of these babies were discharged in Home Oxygen and 135 of these babies were eligible for Palivizumab (JCVI).

\begin{tabular}{|c|c|c|c|}
\hline Number of babies & $\begin{array}{l}\text { Babies } \\
\text { immunised } \\
\text { according to } \\
\text { JCVI criteria }\end{array}$ & $\begin{array}{l}\text { Babies with CLD not } \\
\text { discharged in Oxygen } \\
\text { that would be } \\
\text { eligible }\end{array}$ & P Value \\
\hline Total & 135 & 53 & \\
\hline $\begin{array}{l}\text { Confirmed RSV hospitalisations } \\
\text { following discharge from } \\
\text { neonatal unit within } 1 \text { st year } \\
\text { of life }\end{array}$ & $13(9.6 \%)$ & $3(5.66 \%)$ & 0.56 \\
\hline Average LOS in days (IQR) & 10.3 days & 7.3 days & $\begin{array}{l}\text { Unable to } \\
\text { calculate due } \\
\text { to small } \\
\text { numbers }\end{array}$ \\
\hline
\end{tabular}

Conclusion The RSV hospitalisation rate was lower in preterm infants who did not qualify for Palivizumab compared to infants who qualified according to JCVI guideline but this difference was not statistically significant. A large prospective multi-centre study is required to ascertain the clinical and economic benefits of including the wider group for Palivizumab prophylaxis.

\section{P83 RESPIRATORY MORBIDITY AND ASSESSMENT OF RESPIRATORY RISK FACTORS IN SCHOOL AGED CHILDREN WITH SEVERE NEUROLOGICAL IMPAIRMENT}

L Thomson, L Gardner, K Sharp, P Davies. Royal Hospital for Children, Glasgow, UK

\subsection{6/thoraxjnl-2017-210983.225}

Introduction Respiratory morbidity is well documented in children with neurological impairment. Early intervention programmes to identify children at high risk are not well established. We proactively reviewed respiratory status of children with severe neurological impairment in local special schools to identify and manage those at high risk.

Methods School nurses identified all children with severe neurological impairment (GMFCS IV and V). All had a multidisciplinary respiratory assessment at school. Data was collected on 